\title{
A new fireworm (Amphinomidae) from the Cretaceous of Lebanon identified from three-dimensionally preserved myoanatomy
}

\author{
Luke A. Parry ${ }^{1,2}$, Paul Wilson ${ }^{1}$, Dan Sykes ${ }^{3}$, Gregory D. Edgecombe ${ }^{2^{*}}$ and Jakob Vinther ${ }^{1^{*}}$
}

\begin{abstract}
Background: Rollinschaeta myoplena gen. et sp. nov is described from the Late Cretaceous (Cenomanian) Konservat-Lagerstätten of Hakel and Hjoula, Lebanon. The myoanatomy of the fossils is preserved in exceptional detail in three dimensions as calcium phosphate, allowing the musculature of the body wall, gut and parapodia to be reconstructed in detail.

Results: The major muscle groups of polychaetes can be identified in Rollinschaeta, including longitudinal muscle bands, circular muscles, oblique muscles, the parapodial muscle complex and the gut musculature, with a resolution sufficient to preserve individual fibres. To allow meaningful comparison with the phosphatized fossil specimens, extant polychaetes were stained with iodine and visualised using microCT. Rollinschaeta myoplena possesses two pairs of dorsal longitudinal muscles, dorsal and ventral circular muscles and a single pair of ventral longitudinal muscles. While six longitudinal muscle bands are known from other polychaete groups, their presence in combination with circular muscles is unique to Amphinomidae, allowing these fossils to be diagnosed to family level based solely on their myoanatomy. The elongate, rectilinear body and equally sized, laterally projecting parapodia of Rollinschaeta are found only within Amphinominae, demonstrating that the Cretaceous species is derived amongst Amphinomida.

Conclusion: The uniquely preserved myoanatomy of Rollinschaeta has allowed diagnosis of a fossil annelid to subfamily level using microCT as a comparative tool for exploring myoanatomy in fossil and extant polychaetes. Our results demonstrate that fossilized muscles can provide systematically informative anatomical detail and that they should be studied when preserved.
\end{abstract}

Keywords: Annelida, Polychaetes, Amphinomidae, Cretaceous, Rollinschaeta, Musculature

\section{Background}

Although relatively rare, polychaete body fossils provide key insights into the evolution of annelids, such as the sequence of character acquisition in the annelid stem group [1-3], the affinities of enigmatic extinct groups [4] and diverse ancient faunas $[5,6]$. Important examples of the latter include the early Cambrian Sirius Passet [1, 7], middle Cambrian Burgess Shale [8], Ordovician Fezuoata

\footnotetext{
* Correspondence: g.edgecombe@nhm.ac.uk; jakob.vinther@bristol.ac.uk 2Department of Earth Sciences, The Natural History Museum, Cromwell Road, London SW7 5BD, UK

${ }^{1}$ Bristol Life Sciences Building, University of Bristol, 24 Tyndall Avenue, Bristol BS8 1TH, UK

Full list of author information is available at the end of the article
}

Biota [4] and Carboniferous Mazon Creek [5, 6]. Fossil annelids can be found in a wide array of preservational modes and depositional settings, ranging from carbonaceous compressions in offshore marine settings, within ironstone concretions in marginal marine settings [5] and by authigenic mineralisation via pyritisation $[4,9]$ or phosphatisation [10].

Despite the preservation of labile tissues in the biotas highlighted above, polychaete fossils are typically classified based on the morphology of recalcitrant structures, such as the hollow, calcareous chaetae of two amphinomid species from the Carboniferous [11], the distinctive chaetal baskets of flabelligerids from Mazon Creek [6], 
or the presence of distinctive jaws [5, 12]. More rarely, the affinities of fossil polychaetes are determined using the morphology of soft anatomy. Key examples include the preservation of soft parts in machaeridians [4] and the three-dimensionally preserved Palaeozoic polychaetes Arkonips [9] and Kenostrychus [13].

The polychaete fauna of the Cretaceous KonservatLagerstätten of Hakel, Hjoula and Al-Namoura , Lebanon was described by Bracchi and Allessandrello [12], who assigned the fossils to six families with seven genera and 17 species. These taxa are all contained within the orders Phyllodocida and Eunicida and were primarily identified based on jaw morphology. Soft tissues are generally poorly preserved in these fossils, although paired longitudinal muscle bands were highlighted in a single specimen of Ferragutia cenomania (Goniadidae) [12]. These two orders represent the bulk of diversity of errant polychaetes, with only two families (Euphrosinidae and Amphinomidae) contained within the third order, Amphinomida. The close relationship between these three orders is well established based on morphological data $[14,15]$, but is currently uncertain based on phylogenomic data [16].

Herein, we describe a new species of Cretaceous polychaete from Lebanon with extensive preservation of muscle tissue, including the muscles of the body wall, gut and parapodia. Polychaete body fossils that preserve evidence of muscle anatomy are rare and at present are known only from Sirius Passet [7], the Silurian Eramosa biota [17], the Jurassic of Solnhofen [10], the Cretaceous Lägerstatten of Lebanon [12] and a possible annelid from the Wattendorf Plattenkalk [18].

The new species preserves myoanatomy in exquisite detail, including the body wall circular and longitudinal muscles, gut musculature and parapodial muscle complex. This is compared with the myoanatomy of errant polychaetes from the published literature as well as novel data from CT scanning of extant polychaetes. The described myoanatomy is unique to the Amphinomidae and the new taxon, formally named as Rollinschaeta myoplena gen. nov. sp. nov., preserves further characters unique to Aciculata and Amphinomida. Due to the exceptional state of preservation of muscles in this taxon, it currently has the best-known myoanatomy of any fossil annelid and perhaps any fossil animal besides those preserved in amber [19].

\section{Results and discussion Preservation}

The fossils are preserved in three dimensions as white calcium phosphate in fine-grained sublithographic limestones (Figs. 1 and 2). They are dorso-ventrally compressed and split randomly such that different muscle groups are exposed in different specimens. Preservation is largely limited to muscle tissue. Chaetae are poorly preserved, with aciculae preserved as rust-coloured impressions embedded in the parapodial musculature (Fig. 3c and f), and external chaetae preserved as iron oxide stains along the margins of the parapodia. Preservation of cuticle and external morphological features is absent except for rare projections from the parapodia interpreted as dorsal and ventral parapodial cirri (Fig. 3c and $\mathrm{f}$ ). Preservation of muscle anatomy in this taxon is pervasive and apparently independent of size, with juvenile specimens only $39 \mathrm{~mm}$ long also preserving fine details of muscle anatomy (Fig. 1e). Muscle tissue is sufficiently well preserved that muscle fibres can be identified with the naked eye and light microscopy (e.g. Fig. 2e and f) and SEM (Fig. 2c).

In experiments on polychaete decay, muscles were found to be among the first tissues lost to decay, while external chaetae and aciculae are decay resistant [20]. The exceptional preservation of muscles and poor preservation of chaetae in these polychaetes is therefore in conflict with what is known about character loss during decay in annelids, demonstrating a need to disentangle patterns of decay and preservation in taphonomic studies. The unique and exquisite preservation of muscle tissue is incomparable to any other polychaete taxon known from Hakel/Hjoula, and shows a taxonomic bias acting at the family level. Such a taphonomic bias in myoanatomical preservation has only been previously documented from supraphyletic taxa [10].

\section{Muscle anatomy}

(a) Body wall muscles The body wall musculature is composed of dorsal and ventral circular muscle bands, with paired dorsal and ventral longitudinal muscle bands. The ventral circular muscle is broken at the midline at the ventral nerve cord, extends to the base of the neuropodia, and is separated into distinct segmental muscle blocks that terminate at segment boundaries (Fig. 2a, d and f). These muscles are overlain by paired longitudinal muscles that are less laterally extensive than the ventral circular muscles, covering approximately half of their width.

The dorsal body wall musculature is composed of paired dorsal longitudinal muscles and adjacent and narrower dorso-lateral longitudinal muscles (Fig. 2b and g). These are overlain by a thin sheet of circular muscle that is poorly and discontinuously preserved (Fig. 2g). There is a break in slope between the dorso-lateral and dorsal longitudinal muscles (Fig. 2g), suggesting that the former at least partially underlie the latter. A schematic reconstruction of the myoanatomy is shown in Fig. $4 \mathrm{~m}$.

(b) Oblique and parapodial muscles 

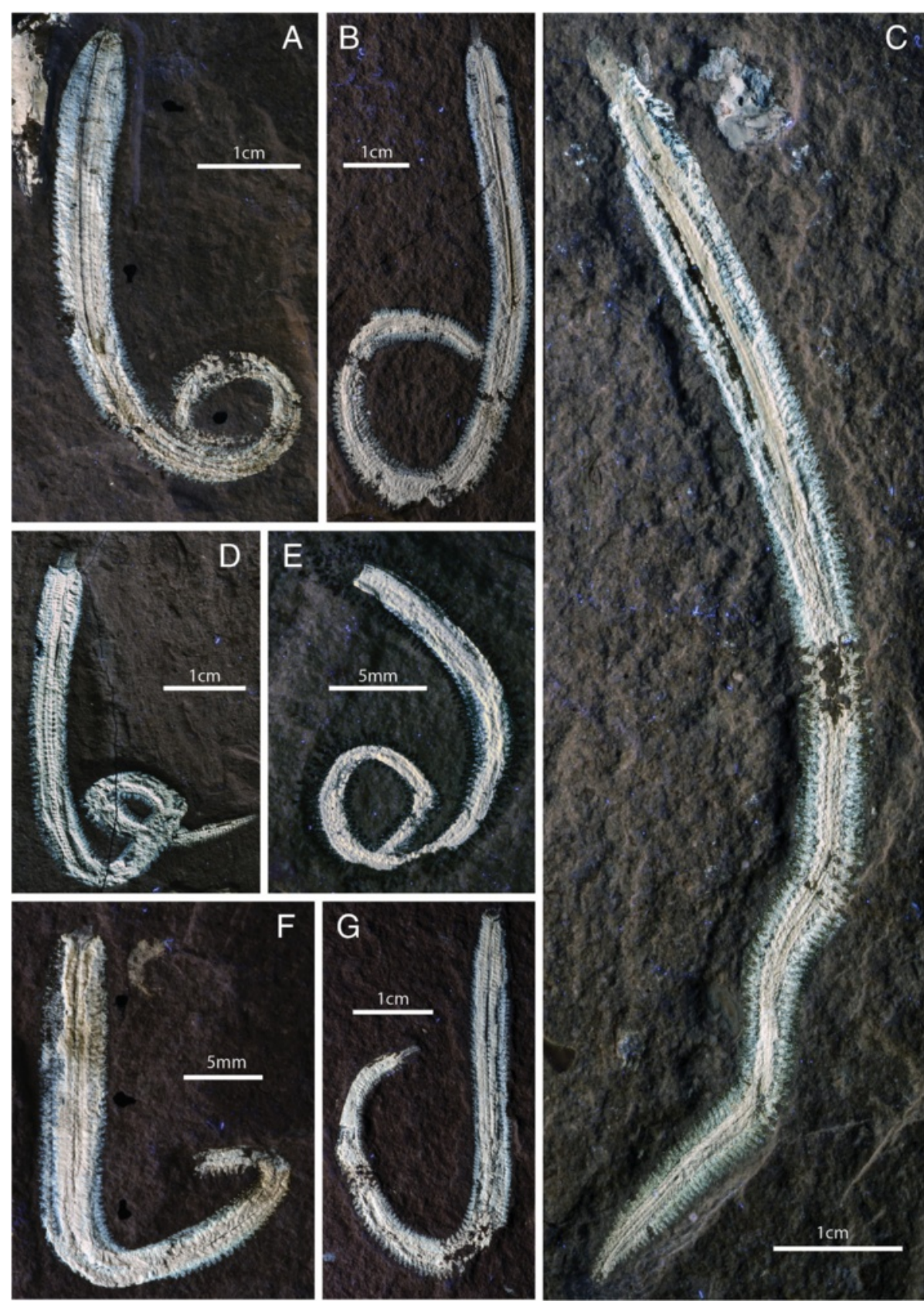

Fig. 1 Specimens of Rollinschaeta myoplena. a) NHMUK PI AN 15074 (holotype); b) AN 15072; c) AN 15077; d) AN 15078; e) AN 15066; f) AN 15075; g) AN 15070. All photographs taken under UV light

The parapodial muscle complex is an elaborate system of muscles that enables the parapodia to perform a range of movements and consequently is difficult to characterise in Rollinschaeta due to compaction and the superposition of muscles associated with each ramus. However, it is possible to observe overlapping portions of musculature associated with their respective rami (Fig. 2d) and rare occurrences of parapodial muscles originating at the midline in association with the ventral nerve cord (Fig. 2e)

\section{Other anatomical characters}

(a) Gross anatomy

The body of Rollinschaeta myoplena numbers up to $\sim 180$ segments in the largest specimens, tapering gently towards the pygidium (Fig. 1). The number 

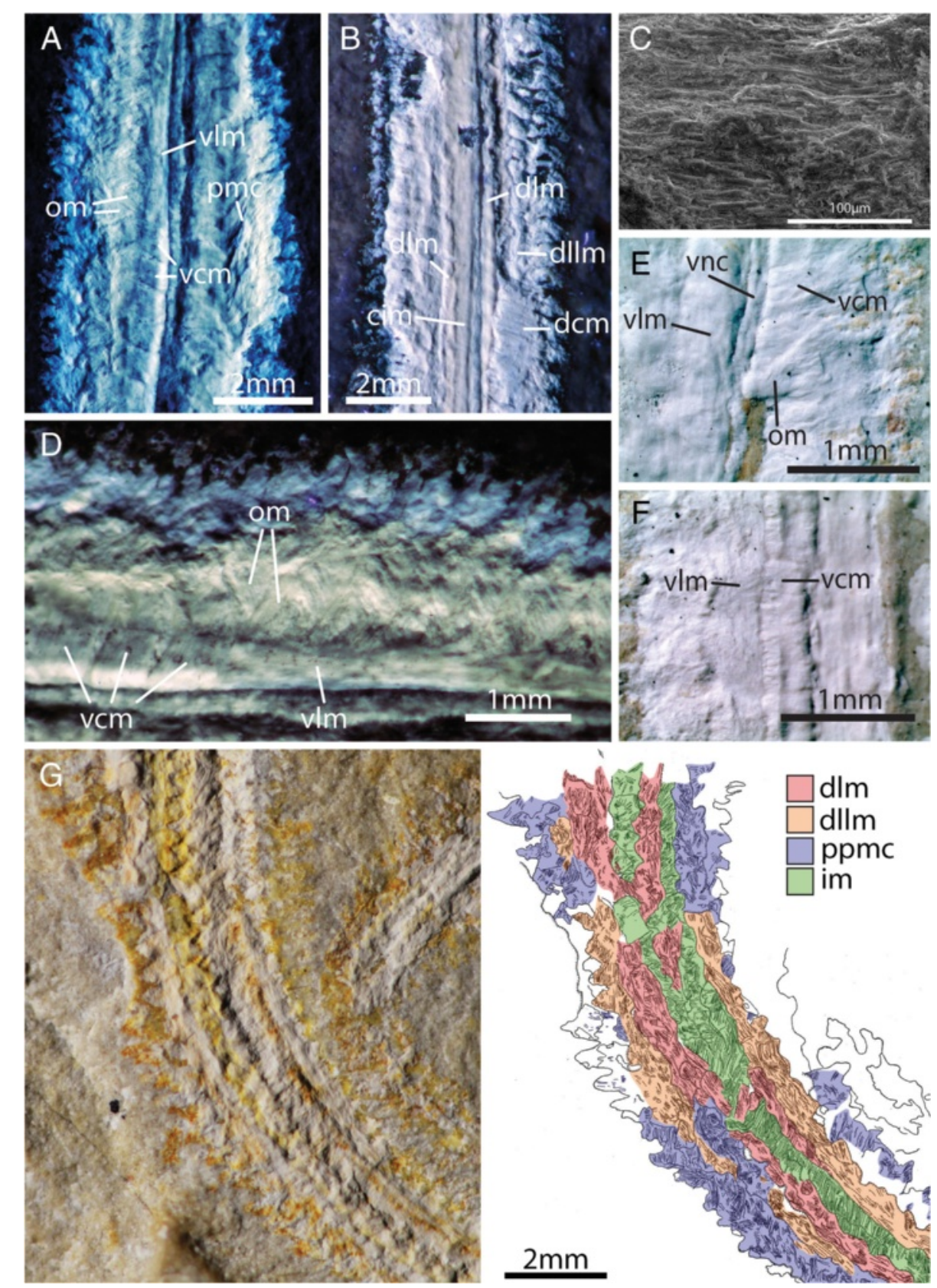

Fig. 2 Myoanatomical features of Rollinschaeta myoplena. a) NHMUK PI AN15070 UV light; b) AN15077 UV light; c) SEM backscatter; d) AN15070 UV light; e) AN15068 light microscopic photomicrograph; f) AN15068 light microscopic photomicrograph; g) AN15074 (holotype), photo under low angle plain light at left, camera lucida drawing at right. Abbreviations: $\mathrm{dlm}$ - dorsal longitudinal muscle, dllm - dorsolateral longitudinal muscle, vlm - ventral longitudinal muscle, vcm - ventral circular muscle, dcm - dorsal circular muscle, om - oblique muscle, vnc - ventral nerve cord, cim - circular intestinal muscle

of chaetigers covaries with the total length of the body suggesting that growth is indeterminate and that segments are added continuously through life. Taper towards the head is less pronounced, with the maximum width posterior of the head, the exact position depending on the state of contraction of the anterior portion of the animal. (b) Head

Specimen AN 15077 preserves a small area of soft tissue that fluoresces under UV light (Fig. 3a). In this specimen, the head is preserved oblique to bedding, so that the head is preserved in lateral aspect. This piece of tissue is therefore dorsal of the everted pharynx and dorsal body wall. Its position 

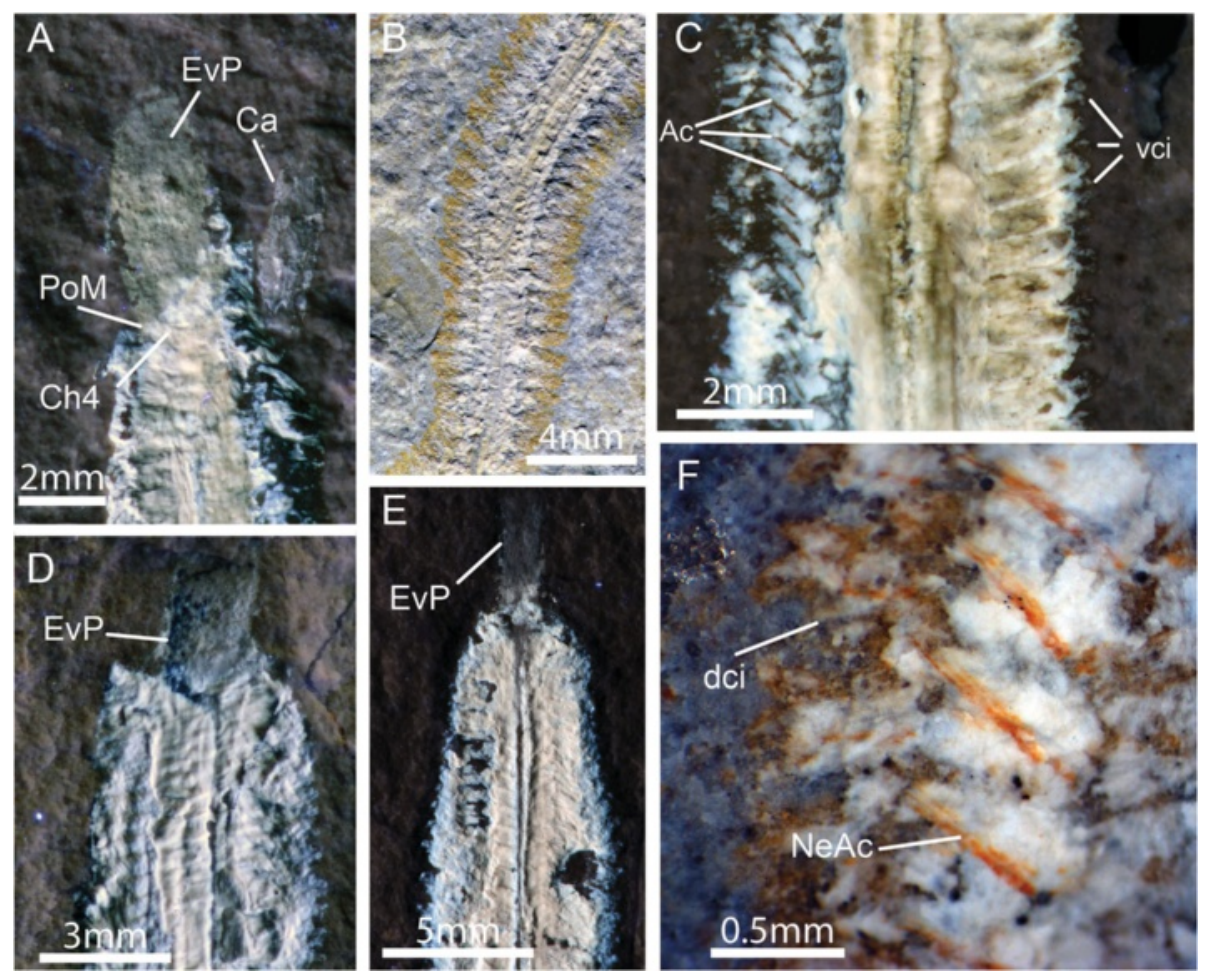

Fig. 3 Additional morphological characters of Rollinschaeta myoplena. a) NHMUK PI AN AN15077 UV light; b) AN15077 plain light; c) AN15075 UV light; d) AN15078 UV light; e) AN15072 UV light; f) AN15075 light microscopic photomicrograph. Abbreviations: dci - dorsal cirrus, vci - ventral cirrus, PoM - posterior margin of mouth, EvP - everted proboscis, Ch4 - chaetiger 4, Ca - caruncle, Ac - aciculae, NeAc - neuroaciculae

and overall appearance is reminiscent of a caruncle. Preservation is poor, however, and it does not preserve any diagnostic morphological details. The arrangement of the anteriormost segments around the head is distinctive, with the posterior of the opening of the buccal cavity occurring at the margin of the third or fourth chaetiger (Fig. 3a). Antennae, palps and cephalised cirri are not preserved. The absence of these structures could be taphonomic given the lack of preservation of non-muscle tissue and cuticle. Musculature had previously been considered absent in the palps of errant annelids [21] and so this could account for their absence, although palp musculature has been identified in Dorvilleidae [22], Nerillidae [23] and Syllidae [24]. Palp muscles are present in the early branching Magelonidae [25] and contractile palps are known from Canadia spinosa, a stem group annelid from the Burgess Shale [3, 26], suggesting that palp muscles have undergone multiple independent losses within errant annelids.

(c) Gut and pharynx

Rollinschaeta myoplena possesses an unarmed, ventral muscular pharynx that opens into a large buccal cavity bounded posteriorly at the fifth chaetiger. The pharynx is eversible, and can be seen at least partly everted in three specimens (Fig. 3a, d and e) in which the buccal cavity is also contracted. The pharynx continues posteriorly into a straight, unbranched gut, preserved as an iron oxide stain with some preservation of gut musculature. The circular musculature of the gut is visible (Fig. 2b), but is poorly preserved compared to the body wall muscles.

(d) Parapodia

The parapodia form short outgrowths of the body wall, commonly surrounded by rusty impressions that are sometimes identifiable as individual chaetae (Fig. 3b). The parapodial rami are equal in size and directed laterally from the body. Internally, the parapodia are supported by aciculae, preserved as iron oxide impregnated moulds. The neuropodia are supported by a bundle of ca. 3 aciculae while the notopodial aciculae are singular (Fig. 3f). While cuticular structures are typically poorly preserved, the parapodia rarely preserve short cirriform projections that are likely dorsal and ventral cirri (Fig. 3c and f).

\section{Comparison with extant polychaetes}

The presence of aciculae and well developed parapodial lobes with cirri in Rollinschaeta clearly invites comparison with living aciculate polychaetes. While internalised 

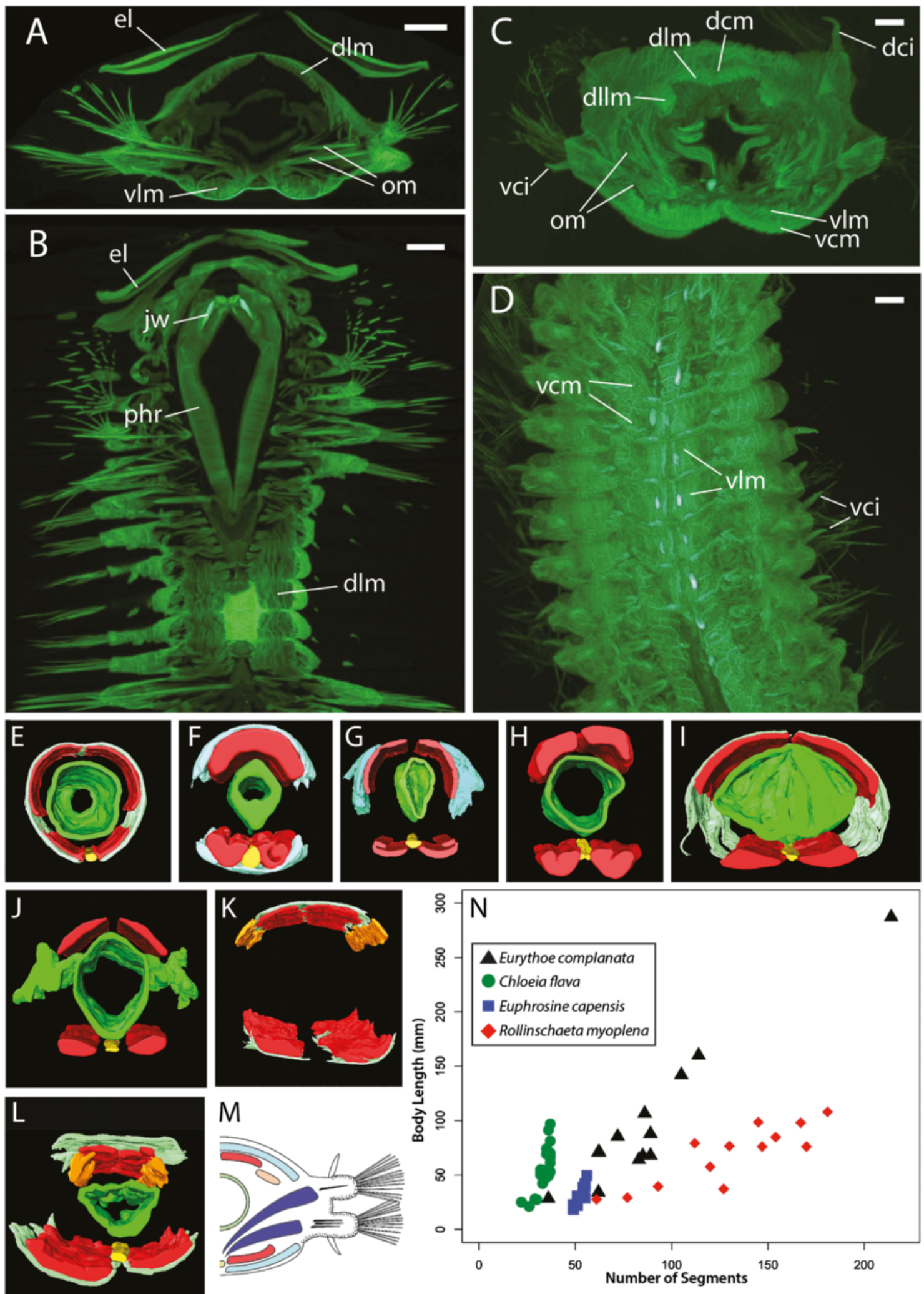

Fig. 4 (See legend on next page.) 
(See figure on previous page.)

Fig. 4 a-b Virtual histological sections of Harmothoe imbricata, scale bars $1 \mathrm{~mm}$. $\mathbf{a}$ - transverse section, $\mathbf{b}$ - sagittal section. c-d virtual histological sections of Eurythoe complanata, scale bars $1 \mathrm{~mm}$. c - transverse section, $\mathbf{d}$ - sagittal section. e-I 3-d models of manually segmented body wall muscles, gut and ventral nerve cord (VNC). Dorsal longitudinal muscles shown in red, dorsolateral longitudinal muscles in orange, circular muscles in blue, VNC in yellow and intestine in green. $\mathbf{e}$ - Glycera alba, $\mathbf{f}$ - Goniada maculata, $\mathbf{g}$ - Hediste diversicolor, $\mathbf{h}$ - Nephtys hombergii, $\mathbf{i}$ - Nothria conchylega, $\mathbf{j}$ - Harmothoe imbricata, $\mathbf{k}$ - Amphinomidae sp. (intestine and VNC not shown), I - Eurythoe complanata. $\mathbf{m}$ - schematic reconstruction of Rollinschaeta myoplena, colour scheme as per E-L, with oblique muscles shown in dark blue. $\mathbf{n}$ - plot of segment number and body length for three extant amphinomid taxa and Rollinschaeta. Abbreviations: el - elytrae, dlm - dorsal longitudinal muscle, dllm - dorsolateral longitudinal muscle, vlm - ventral longitudinal muscle, vcm - ventral circular muscle, dcm - dorsal circular muscle, om - oblique muscle, phr - pharynx, jw - jaw, dci - dorsal cirrus, vci - ventral cirrus

supporting chaetae are known from other annelid taxa, such as Apistobranchidae, Chaetopteridae and Orbiniidae [27], the homology of these chaetae with 'true' aciculae is uncertain and they do not co-occur with dorsal and ventral cirri outside of Aciculata [28]. We CT scannned extant polychaetes (Table 1) in order to make meaningful myoanatomical comparisons with Rollinschaeta (Fig. 4). Our data suggest that myoanatomy is diagnostic at family level for the groups analysed, with closely related taxa such as Goniadidae and Glyceridae (Glyceriformia) having distinctive arrangement of the body wall muscles (Fig. 4e and f).

While annelids are classically considered to possess an outer layer of circular muscle, this is restricted to Clitellata, certain families within Sedentaria (such as Maldanidae and Capitellidae) and Glyceridae (Fig. 4e), in which the outer transversal fibers are interrupted only at the ventral nerve cord [29]. In other families, circular muscles may be poorly developed, form dorsal and/or ventral semicircular layers, or may be absent entirely $[29,30]$. Consequently, the homology of these 'semicircular' muscles with true circular muscles is uncertain $[29,31]$. Amongst polychaetes, single pairs of dorsal and ventral longitudinal muscles are widespread, occurring in both errant and sedentary taxa [31].

The possession of two pairs of dorsal longitudinal muscles in Rollinschaeta is therefore unusual, with such a muscle arrangement only described from Amphinomidae [32] (Fig. 4c, k and l), Polynoidae, Aphroditidae and Chrysopetalidae [31].

Polynoidae and Aphroditidae form part of Aphroditiformia, a group of phyllodocidans with dorsal elytrae, and four dorso-ventral acting jaw elements. Dorsolateral longitudinal muscles are not visible in our CT data for Harmothoe imbricata (Polynoidae), circular muscles are absent and the gut contains distinct diverticular pockets (Fig. 4a, b and j). Chrysopetalidae possess paired lateral jaws as well as distinctive paleae on notopodial ridges. Like scaleworms, with which they may be closely related [14], Chrysopetalidae lack circular muscles and possess dorsolateral longitudinal muscles [31,33]. The absence of jaws, elytrae, gut diverticulae, paleae and tentacular cirri in Rollinschaeta suggest that these taxa are not closely related, as is further supported by the presence of circular muscles in Rollinschaeta.
Rollinschaeta myoplena possesses a suite of morphological characters that are shared with Amphinomida. Specifically, the presence of four dorsal and two ventral longitudinal muscle bands in combination with circular muscles is currently only documented from extant Amphinomidae, while there are at present no data on the myoanatomy of Euphrosinidae, their sister group. The placement of the posterior margin of the buccal cavity at an anterior segment is also shared with amphinomids, with the mouth extending to chaetiger 5 in $\mathrm{Her}$ modice [34] and chaetiger 3 in Chloeia flava (pers. obs., NHMUK collection). Parapodia with equally sized rami are also an unusual character among Aciculata, known from taxa such as Nephtyidae and only some members of Amphinomidae [14]. The myoanatomy of Nephtyidae is distinct from that of Amphinomidae and Rollinschaeta in that nephtyids lack circular muscles and possess only a single pair of dorsal longitudinal muscles (Fig. 4h). Dorsolateral longitudinal muscles are also documented in Sphaerodoridae, but unlike Rollinschaeta this taxon lacks typical circular muscles and possesses uniramous parapodia [15, 24, 35].

\section{Comparison with fossil and extant Amphinomida}

Amphinomids have been described as fossils from the Carboniferous in two taxa, Rhaphidiophorus hystrix [5] and Paleocampa anthrax [11]. Owing to the presence of longitudinally striated chaetae, Rhaphidiophorus has been considered a synonym of Paleocampa as this character is otherwise unknown among polychaetes [11]. Equally sized parapodial rami are also known from the Silurian aciculate polychaete Kenostrychus, but this taxon is currently considered a primitive phyllodocidan [13].

The internal phylogeny of extant Amphinomidae is well characterised, with genera partitioned into two distinct clades [36, 37]. Amphinominae contains taxa with a grossly rectilinear body plan such as Hermodice and Eurythoe whereas Archinominae contains spindleshaped genera such as Chloeia and Archinome. While previous authors have been hesitant to identify the presence of a rectilinear body shape as apomorphic for Amphinominae [36], a fusiform body shape is present in Euphrosinidae, the sister group of Amphinomidae, as well as the oldest fossil amphinomids from the Carboniferous. This suggests 
Table 1 Details of extant taxa used for CT scanning

\begin{tabular}{|c|c|c|c|c|c|c|}
\hline Taxon & Family & Locality & Exposure (ms) & X-ray kv & X-ray ua & Voxel size $(\mathrm{mm})$ \\
\hline Nothria conchylega & Onuphidae & Baffin Bay, Canada & 500 & 165 & 160 & 0.005 \\
\hline Eurythoe complanata & Amphinominae & Puerto de la Cruz, Tenerife, Canary Islands & 500 & 165 & 160 & 0.007 \\
\hline Archinome cf. tethyana & Archinominae & Snake Pit vent field, Mid-Atlantic Ridge & 708 & 100 & 150 & 0.009 \\
\hline Goniada maculata & Goniadidae & ENE of Deget, off Frederikshavn, N Kattegat, Denmark & 354 & 160 & 160 & 0.005 \\
\hline Glycera alba & Glyceridae & Frederikshavn, N Kattegat, Denmark & 354 & 160 & 160 & 0.005 \\
\hline Hediste diversicolor & Nereididae & W of Nibe Bredning, Limfjorden, N. Denmark & 354 & 160 & 160 & 0.005 \\
\hline Harmothoe imbricata & Polynoidae & Bredefjord, S Greenland, Rink & 500 & 165 & 160 & 0.01 \\
\hline Nephtys hombergii & Nephtyidae & Kaas Bredning, Limfjorden, N. Denmark & 354 & 160 & 160 & 0.005 \\
\hline
\end{tabular}

that the fusiform body shape is plesiomorphic, although the phylogenetic placement of Rhaphidiophorus and Paleocampa relative to living taxa is as yet unresolved, since they only preserve amphinomidan plesiomorphies such as calcareous chaetae [11].

The rectilinear morphology of Rollinschaeta is therefore consistent with an affinity with Amphinominae, supporting a position nested within the Amphinomidae. This is corroborated by comparisons of segment addition and growth with extant amphinomids and euphrosinids. Segment number is fixed in several fusiform species whereas in rectilinear taxa (including Rollinschaeta) segments are added continuously throughout life. For example in Chloeia flava segment number is fixed at 37 [38], after which the animal increases in size without the addition of further segments (Fig. 4n) and segment constancy is also known from the fossil Paleocampa [11]. An indeterminate segment number is known for Cryptonome, a member of the Amphinominae [37], and a linear dependence of segment number on body size is indicated in Fig. 4 for both Rollinschaeta and Eurythoe, with both taxa adding in excess of 150 segments.

\section{Systematic palaeontology}

This published work and the nomenclatural acts it contains have been registered in ZooBank: http://zooban k.org/urn:lsid:zoobank.org:pub:9122F602-F4CD-4431-A5 BA-FE31FB41D24A.

Phylum: Annelida Lamarck, 1809

Subclass: Aciculata Rouse and Fauchald, 1997

Family: Amphinomidae

Subfamily: Amphinominae

Genus: Rollinschaeta gen. nov.

Derivation of name: Rollins - for Henry Rollins + chaeta, from Late Latin, for a bristle, seta or long hair.

Diagnosis: Body ranges from 27 to $108 \mathrm{~mm}$ in length with 61 to 181 segments tapering gently towards a small pygidium and markedly from anterior chaetigers towards prostomium. Parapodia well developed, biramous with cirri at base of each ramus. Rami approximately equal in size. Aciculae singular in notopodium and present in bundles of ca. 3 in neuropodium. External parapodial chaetae poorly preserved but capillary chaetae present. Pharynx muscular and eversible, with posterior margin of mouth abutting chaetiger 3. Caruncle possibly present. Head appendages including lateral and median antennae and palps, if present, not preserved. Paired dorsal, dorsolateral and ventral longitudinal muscle bands present. Ventral circular muscles present, discontinuous across segment boundaries. Dorsal circular muscles present.

Species: Rollinschaeta myoplena gen. nov. sp. nov.

Derivation of name: myo, from Classical Greek, for muscle + plenus, from Latin, for plump or filled.

Diagnosis: as for genus.

Holotype: NHMUK PI AN 15074, from Hjoula.

Type locality: A quarry northwest of the town of Hjoula, Lebanon, $34^{\circ} 07^{\prime} 59.43^{\prime \prime} \mathrm{N} 35^{\circ} 44^{\prime} 39.42^{\prime \prime}$ E.

Paratypes: 13 specimens, NHMUK PI AN 15075, AN 15076 (type locality, Hjoula), AN 15061, AN 15066, AN 15067, AN 15068, AN 15070, AN 15071, AN 15072, AN 15073, AN 15077, AN 15078, AN 15079, all from Hakel.

\section{Conclusions}

We describe in this paper an amphinomid polychaete from the Late Cretaceous (Cenomanian) deposits of Hakel and Hjoula, Lebanon. To our knowledge, this is the first time an organism could be diagnosed exclusively by preserved myoanatomy. Fossil muscle tissue has largely been considered a taphonomic curiosity and has rarely figured in evolutionary studies [39]. While well-preserved myoanatomy is rare, it is likely to provide novel information about ancient body plans and their functional morphology and should be studied in detail when available. Furthermore we demonstrate that microCT is a fast, non-destructive and effective method for making meaningful myoanatomical comparisons between extant and fossil taxa.

\section{Methods}

A total of 14 specimens from the Late Cretaceous (Cenomanian) limestones of Hakel and Hjoula, northwest Lebanon, were examined (see type material for registrations). All were collected from privately-owned quarries and were acquired by transfer of title. 
Specimens were illuminated using low angle lighting and under UV to enhance the contrast between the specimen and matrix and highlight muscle groups. In order to allow comparison of the myoanatomy of Rollinschaeta with extant polychaetes, specimens were micro-CT scanned. These were first stained by submersion in $1 \%$ iodine in $70 \% \mathrm{EtOH}$. The specimen was dehydrated through a graded alcohol series to $100 \% \mathrm{EtOH}$ and then chemically dried using Hexamethyldisilazane (HMDS) to enhance contrast [40]. The dried specimens were then micro-CT scanned with a Nikon HMX ST 225 system, housed in the Natural History Museum. 3,142 projections were collected for each scan and reconstructed using a modified Feldkamp backprojection algorithm [41] in CT Pro (Nikon Metrology, Tring, UK). The data were then manually segmented and visualised using Avizo 8.0 (FEI). Segment counts and approximate measurements of body length were taken from the extant Amphinomida Euphrosine capensis (Euphrosinidae) and Chloeia flava and Eurythoe complanata (Amphinomidae) in order to compare segment addition, growth and gross anatomy with Rollinschaeta.

Fossil specimens were imaged a Nikon D90 and Nikon AF-S VR Micro-Nikkor $105 \mathrm{~mm} \mathrm{f} / 2$ IF-ED lens (with or without a $2 x$ teleconverter) using $\mathrm{UV}$ and plain light as well as light microscopy to generate high resolution images and maximise contrast between different muscle groups. Interpretive drawings were made using a camera lucida.

\section{Competing interests}

We declare no competing interests.

\section{Authors' contributions}

JV, GDE and LAP designed the study. LAP photographed the fossils and performed the initial identification. PW performed SEM analyses, made camera lucida drawings and segmented the CT data. DS, PW and LAP stained and scanned the extant polychaetes and processed the CT data. LAP wrote the manuscript. All authors edited and approved the final manuscript.

\footnotetext{
Acknowledgements

Fossil specimens were sourced by Martin Munt, with support from the NHM Collections Committee Collection Enhancement Fund. We would like to thank Danny Eibye-Jacobsen for kindly donating specimens for CT scanning, Emma Sherlock for access to the NHM polychaete collection, and Gordon Paterson for the specimen of Archinome. LAP thanks Joseph Keating for help with Avizo. LP is funded by NERC grant NE/L501554/1.
}

\section{Author details}

${ }^{1}$ Bristol Life Sciences Building, University of Bristol, 24 Tyndall Avenue, Bristol BS8 1TH, UK. ²Department of Earth Sciences, The Natural History Museum, Cromwell Road, London SW7 5BD, UK. ${ }^{3}$ maging and Analysis Centre, The Natural History Museum, Cromwell Road, London SW7 5BD, UK.

Received: 27 July 2015 Accepted: 11 November 2015

Published online: 17 November 2015

\section{References}

1. Vinther J, Eibye-Jacobsen D, Harper DA. An Early Cambrian stem polychaete with pygidial cirri. Biol Lett. 2011;7(6):929-32.

2. Parry L, Tanner A, Vinther J. The origin of annelids. Palaeontology. 2014; 57(6):1091-103.
3. Parry L, Vinther J, Edgecombe GD. Cambrian stem-group annelids and a metameric origin of the annelid head. Biol Lett. 2015;11:20150763.

4. Vinther J, Van Roy P, Briggs DEG. Machaeridians are Palaeozoic armoured annelids. Nature. 2008:451:185-8.

5. Thompson I. Errant polychaetes (Annelida) from the Pennsylvanian Essex fauna of northern Illinois. Palaeontographica Abt A. 1979;163(4-6):169-99.

6. Hay AA. Flabelligerida from the Francis Creek Shale of Illinois. J Paleontol. 2002;76(4):764-6.

7. Conway Morris S, Peel J. The earliest annelids: Lower Cambrian polychaetes from the Sirius Passet Lagerstatte, Peary Land, North Greenland. Acta Palaeontol Pol. 2008;53(1):135-46.

8. Conway Morris S. Middle Cambrian polychaetes from the Burgess Shale of British Columbia. Phil Trans R Soc London B, Biol Sci. 1979;285:227-74.

9. Farrell U, Briggs DEG. A pyritized polychaete from the Devonian of Ontario. Proc R Soc Lond B Biol Sci. 2007;274(1609):499-504.

10. Wilby PR, Briggs DEG. Taxonomic trends in the resolution of detail preserved in fossil phosphatized soft tissues. Geobios. 1997;30:493-502.

11. Pleijel F, Rouse GW, Vannier J. Carboniferous fireworms (Amphinomida: Annelida), with a discussion of species taxa in palaeontology. Invert Syst. 2005;18(6):693-700.

12. Bracchi $\mathrm{G}$, Alessandrello A. Paleodiversity of the free-living polychaetes (Annelida, Polychaeta) and description of new taxa from the Upper Cretaceous Lagerstätten of Haqel, Hadjula and Al-Namoura (Lebanon). Mem Soc Ital Sci Nat Mus Civico Stor Nat Milano. 2005;32(3):1-64.

13. Sutton MD, Briggs DEG, Siveter DJ, Siveter DJ. A three-dimensionally preserved fossil polychaete worm from the Silurian of Herefordshire, England. Proc R Soc Lond B Biol Sci. 2001;268:2355-63.

14. Rouse GW, Fauchald K. Cladistics and polychaetes. Zool Scripta. 1997;26(2):139-204.

15. Rouse G, Pleijel F. Polychaetes. Oxford: Oxford University Press; 2001.

16. Weigert A, Helm C, Meyer M, Nickel B, Arendt D, Hausdorf B, et al. Illuminating the base of the annelid tree using transcriptomics. Mol Biol Evol. 2014;31(6):1391-401.

17. von Bitter PH, Purnell MA, Tetreault DK, Stott CA. Eramosa Lagerstätte-exceptionally preserved soft-bodied biotas with shallowmarine shelly and bioturbating organisms (Silurian, Ontario, Canada). Geology. 2007;35(10):879-82.

18. Chellouche P, Fürsich FT, Mäuser M. Taphonomy of neopterygian fishes from the Upper Kimmeridgian Wattendorf Plattenkalk of Southern Germany. Palaeobiodiversity Palaeoenvironments. 2012;92(1):99-117.

19. Grimaldi D, Bonwich E, Delannoy M, Doberstein S. Electron microscopic studies of mummified tissues in amber fossils. Amer Mus Novitates. 1994;3097:1-31.

20. Briggs DEG, Kear AJ. Decay and preservation of polychaetes; taphonomic thresholds in soft-bodied organisms. Paleobiology. 1993;19(1):107-35.

21. Purschke G, Bleidorn C, Struck T. Systematics, evolution and phylogeny of Annelida-a morphological perspective. Mem Mus Victoria. 2014;71:247-69.

22. Filippova A, Purschke G, Tzetlin AB, Müller M. Three-dimensional reconstruction of the F-actin musculature of Dorvillea kastjani (Dorvilleidae, Polychaeta) by means of phalloidin-labelling and CLSM. Scientia. 2006;70:293-300.

23. Müller M, Worsaae K. CLSM analysis of the phalloidin-stained muscle system in Nerilla antennata, Nerillidium sp. and Trochonerilla mobilis (Polychaeta; Nerillidae). J Morphol. 2006;267:885-96.

24. Filippova A, Purschke G, Tzetlin AB, Müller M. Musculature in polychaetes: comparison of Myrianida prolifera (Syllidae) and Sphaerodoropsis sp. (Sphaerodoridae). Invert Biol. 2010;129(2):184-98.

25. Filippova A, Purschke $G$, Tzetlin AB, Müller MC. Reconstruction of the musculature of Magelona cf. mirabilis (Magelonidae) and Prionospio cirrifera (Spionidae)(Polychaeta, Annelida) by phalloidin labeling and CLSM. Zoomorphology. 2005;124(1):1-8.

26. Eibye-Jacobsen D. A reevaluation of Wiwaxia and the polychaetes of the Burgess Shale. Lethaia. 2004;37(3):317-35.

27. Hausen $\mathrm{H}$. Chaetae and chaetogenesis in polychaetes (Annelida). Hydrobiologia. 2005;535(1):37-52.

28. Eibye-Jacobsen D, Vinther J. Reconstructing the ancestral annelid. J Zool Syst Evol Res. 2012;50(1):85-7.

29. Purschke G, Müller M. Evolution of body wall musculature. Integr Comp Biol. 2006:46(4):497-507.

30. Tzetlin A, Purschke G. Fine structure of the pharyngeal apparatus of the pelagosphera larva in Phascolosoma agassizii (Sipuncula) and its phylogenetic significance. Zoomorphology. 2006;125(3):109-17.

31. Tzetlin A, Filippova A. Muscular system in polychaetes (Annelida). Hydrobiologia. 2005;535:113-26. 
32. Marsden JR. Segmental musculature and locomotion in Hermodice carunculata (Polychaeta: Amphinomidae). J Morphol. 1966;119(2):259-76.

33. Tzetlin AB, Zhadan A, Ivanov I, Müller M, Purschke G. On the absence of circular muscle elements in the body wall of Dysponetus pygmaeus (Chrysopetalidae, 'Polychaeta', Annelida). Acta Zool. 2002;83(1):81-5.

34. Marsden JR. The digestive tract of Hermodice carunculata (Pallas). Polychaeta: Amphinomidae. Can J Zool. 1963;41(2):165-84.

35. Helm C, Capa M. Comparative analyses of morphological characters in Sphaerodoridae and allies (Annelida) revealed by an integrative microscopical approach. Front Mar Sci. 2015;1(82):1-15.

36. Borda E, Yáñez-Rivera B, Ochoa GM, Kudenov JD, Sanchez-Ortiz C, Schulze A, et al. Revamping Amphinomidae (Annelida: Amphinomida), with the inclusion of Notopygos. Zool Scripta. 2015;44(3):324-33.

37. Borda E, Kudenov JD, Bienhold C, Rouse GW. Towards a revised Amphinomidae (Annelida, Amphinomida): description and affinities of a new genus and species from the Nile Deep-sea Fan, Mediterranean Sea. Zool Scripta. 2012:41(3):307-25.

38. Imajima M. Polychaetous annelids from Sagami Bay and Sagami Sea collected by the Emperor Showa of Japan and deposited at the Showa Memorial Institute, National Science Museum, Tokyo (II): orders included within the Phyllodocida, Amphinomida, Spintherida and Eunicida. Nat Sci Mus Monogr. 2003;23:1-221.

39. Budd GE. Arthropod body-plan evolution in the Cambrian with an example from anomalocaridid muscle. Lethaia. 1998;31(3):197-210.

40. Paterson GL, Sykes D, Faulwetter S, Merk R, Ahmed F, Hawkins LE, et al. The pros and cons of using micro-computed tomography in gross and micro-anatomical assessments of polychaetous annelids. Mem Mus Victoria. 2014;71:237-46.

41. Feldkamp L, Davis $L$, Kress J. Practical cone-beam algorithm. J Opt Soc Amer. 1984;1(6):612-9.

\section{Submit your next manuscript to BioMed Central and take full advantage of:}

- Convenient online submission

- Thorough peer review

- No space constraints or color figure charges

- Immediate publication on acceptance

- Inclusion in PubMed, CAS, Scopus and Google Scholar

- Research which is freely available for redistribution 